\title{
The southern Brazilian grassland biome: soil carbon stocks, fluxes of greenhouse gases and some options for mitigation
}

\author{
Pillar, VD. ${ }^{a *}$, Tornquist, $C G .^{b}$ and Bayer, $C .^{b}$ \\ aDepartamento de Ecologia, Instituto de Biociências, Universidade Federal do Rio Grande do Sul - UFRGS, \\ Av. Bento Gonçalves, 9500, CEP 91540-000, Porto Alegre, RS, Brazil

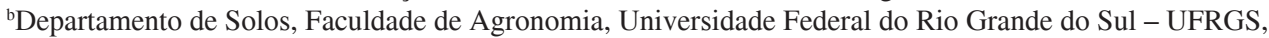 \\ Av. Bento Gonçalves, 7712, CEP 90540-000, Porto Alegre, RS, Brazil \\ *e-mail: vpillar@ufrgs.br \\ Received February 13, 2012 - Accepted February 29, 2012 - Distributed August 31, 2012
}

(With 5 figures)

\begin{abstract}
The southern Brazilian grassland biome contains highly diverse natural ecosystems that have been used for centuries for grazing livestock and that also provide other important environmental services. Here we outline the main factors controlling ecosystem processes, review and discuss the available data on soil carbon stocks and greenhouse gases emissions from soils, and suggest opportunities for mitigation of climatic change. The research on carbon and greenhouse gases emissions in these ecosystems is recent and the results are still fragmented. The available data indicate that the southern Brazilian natural grassland ecosystems under adequate management contain important stocks of organic carbon in the soil, and therefore their conservation is relevant for the mitigation of climate change. Furthermore, these ecosystems show a great and rapid loss of soil organic carbon when converted to crops based on conventional tillage practices. However, in the already converted areas there is potential to mitigate greenhouse gas emissions by using cropping systems based on no soil tillage and cover-crops, and the effect is mainly related to the potential of these crop systems to accumulate soil organic carbon in the soil at rates that surpass the increased soil nitrous oxide emissions. Further modelling with these results associated with geographic information systems could generate regional estimates of carbon balance.
\end{abstract}

Keywords: pampa biome, management, soil organic matter, global warming, climate change.

\section{Campos do sul do Brasil: estoques de carbono no solo, fluxos de gases de efeito estufa e algumas opções para mitigação}

\begin{abstract}
Resumo
Os campos do sul do Brasil são ecossistemas naturais com alta diversidade e têm sido há séculos importantes para a atividade pastoril e para outros importantes serviços ambientais. Este trabalho aponta os principais fatores que controlam os processos ecossistêmicos, revisa e discute os dados disponíveis sobre os estoques de carbono no solo e as emissões de gases de efeito estufa dos solos, e sugere oportunidades de mitigação das mudanças climáticas. A pesquisa sobre as emissões de carbono e gases de efeito estufa nos campos do sul do Brasil é recente e os resultados são ainda fragmentados. Os dados disponíveis indicam que os ecossistemas campestres naturais manejados adequadamente contêm estoques importantes de carbono orgânico no solo e, portanto, sua conservação é relevante para a mitigação das mudanças climáticas. Além disso, esses ecossistemas apresentam uma grande e rápida perda de carbono orgânico do solo quando convertidos para lavouras com preparo convencional do solo. No entanto, nas áreas já convertidas, há potencial para mitigar as emissões de gases de efeito estufa por meio de sistemas de cultivo usando plantio direto e rotações de culturas baseadas em plantas de cobertura de solo. O efeito está relacionado principalmente ao potencial desses sistemas de cultivo para acumular matéria orgânica do solo em taxas que superam o aumento das emissões de óxido nitroso. O uso de modelos com esses resultados associados aos sistemas de informação geográfica poderá gerar estimativas regionais de balanço de carbono.
\end{abstract}

Palavras-chave: bioma pampa, manejo, matéria orgânica do solo, mudanças climáticas, aquecimento global. 


\section{Introduction}

The southern Brazilian grasslands, known as campos, are natural ecosystems that have characterised the region well before the expansion of forests occurred from the mid-Holocene (Behling et al., 2009; Behling and Pillar, 2007; Dümig et al., 2008). These grasslands offer important environmental services. They have been the main source of forage for grazing livestock, which in Rio Grande do Sul has been a major economic activity (Pillar et al., 2009). They harbour high biodiversity, with about 2,200 plant species, whose knowledge of potential uses is still incipient (Boldrini, 2009), and high diversity of animal wildlife including endangered species (Bencke, 2009). These grassland ecosystems ensure the conservation of surface water resources (Geahl et al., 2010; Kozera et al., 2009) and groundwater (Melo, 2009), and offer scenic attractions with major tourism potential. Furthermore, their conservation through adequate management has implications for the carbon balance in the soil and on greenhouse gas emissions, thus contributing to the effort to mitigate global climate change (Soussana, 2009).

Soils under these grasslands contain large stocks of soil organic matter (Tornquist et al., 2009a). However, there is a trend of land use change in these ecosystems, markedly the conversion to annual grain crop agriculture and/or silviculture, which accelerates soil organic matter decomposition, decreases soil organic matter stocks and enhances greenhouse gas emissions. Concurrently, sustainable grazing management through optimized stocking rates and supplemental nutrient additions has been shown to increase biomass production, sequester carbon, conserve biodiversity and increase the resilience of the grassland ecosystem, thereby contributing to the adaptation of livestock production systems to climate change (Conant et al., 2001; Schuman et al., 2002; Soussana, 2009; Conant, 2010).

Here we present a general outline on factors controlling ecosystem processes in the southern Brazilian grassland biome, review available data on soil carbon stocks and greenhouse gases (carbon dioxide- $\mathrm{CO}_{2}$, nitrous oxide$\mathrm{N}_{2} \mathrm{O}$ and methane- $\mathrm{CH}_{4}$ ) emissions from the soils, and discuss opportunities for climate change mitigation by these ecosystems.

\section{Region Characterisation}

The southern Brazilian grasslands (Figure 1), according to the IBGE classification (IBGE, 2004), are included mostly in the Pampa biome in the southern and western regions of the state of Rio Grande do Sul, and discontinuously within the Atlantic forest biome on the highland plateau of southern Brazil. Here we adopt the term southern Brazilian grasslands biome, irrespective of the IBGE biome classification, to refer in general to the former grassland ecosystems in this region that have been conserved or converted into other land uses. However, we will focus our analysis of carbon stocks and emissions on the grasslands of the Pampa biome, for which data is available.

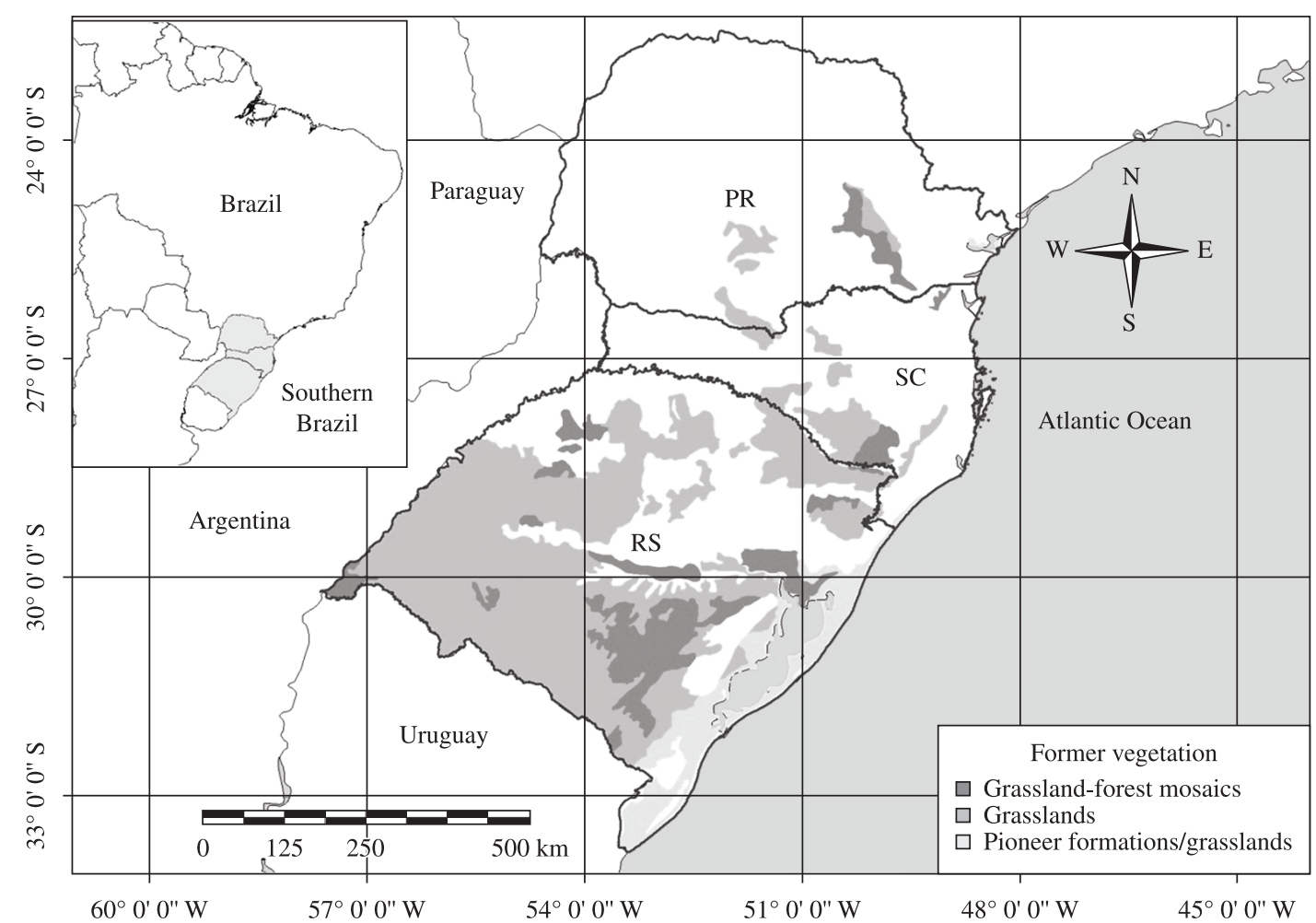

Figure 1. Map of the grassland biome in southern Brazil, adapted from IBGE (2004). The remaining areas (in white) in southern Brazil were forests of the Atlantic Forest biome. 
In some regions the grasslands predominate and form the matrix of the landscape, while in other regions, both in the Pampa biome as in the Atlantic Forest biome, form mosaics associated with isolated patches of forest (regionally known as capões) and riparian forests. These forests are of different sizes and shapes and contain elements of deciduous and semi-deciduous forest, or mixed rain forest with the occurrence of Araucaria angustifolia.

\section{Ecological Determinants}

The dynamics of the southern Brazilian grasslands is associated with the occurrence of certain levels of disturbance by grazing and fire. These disturbances create spatial heterogeneity and allow increasing plant species diversity in the community as the successional processes are renewed, preventing the homogenisation of the community by a few competitively superior species. Evaluations of these disturbances for the southern Brazilian grasslands showed their influence on the diversity of plant species, and hence its importance for biodiversity conservation (Overbeck et al., 2007; Overbeck et al., 2005). Nevertheless, management of grasslands with grazing and/or burning in protected areas is still a real taboo in Brazil (Pillar and Vélez, 2010).

Fire has occurred in these grasslands since the early Holocene, probably of anthropogenic origin (Behling and Pillar, 2007; Behling et al., 2005), and grazing by livestock is present since its introduction in the seventeenth century (Porto, 1954). However, fire and grazing are negatively associated, firstly because where grazing is removed the vegetation becomes more flammable and fires tend to have greater extension and intensity; and secondly, grassland that is properly managed with grazing are less flammable. Therefore, proper grazing management could reduce the need for burning and also the risks of catastrophic fires, which would be of particular relevance in conservation areas, especially considering the contact areas with forest ecosystems. Furthermore, avoiding fire by proper grazing management may increase carbon accumulation in the ecosystem.

There is evidence that large herbivorous grazers have co-evolved with the species of grasses in South America since the early Miocene (MacFadden, 1997; MacFadden, 2005). Grazing by large grazers, therefore, is not a novelty in the evolution of grassland species, and the conjecture that domestic cattle may represent the reintroduction of a process performed before by mega faunal grazers is plausible, with proper consideration of uncertainties regarding population densities. The presence of grazers alters the vegetation structure by selection among palatable and unpalatable plants and also influences micro variation of topography, which can increase the spatial heterogeneity of habitats (Morris, 2000). Management practices that sustain diverse and structurally complex pastures sustain more diverse terrestrial invertebrate assemblages (Reid and Hochuli, 2007), which will likely have consequences in ecosystem processes such as biomass decomposition.

\section{Land Cover and Land Use Changes}

The conservation of the southern Brazilian grasslands has been neglected (Overbeck et al., 2007). In the last three decades, their conversion into agricultural and silvicultural uses reduced the remaining natural grassland vegetation cover in the state of Rio Grande do Sul to only about 50\% of the original (Cordeiro and Hasenack, 2009). In the case of the grasslands (Campos Gerais) in the state of Paraná, remaining grassland cover is less than $10 \%$ of the original distribution (Rocha, 1995).

Besides habitat loss, conversion has also spawned fragmentation of these ecosystems, with consequences on patterns of biodiversity and on the increase in species extinction risks. Furthermore, invasion of species such as exotic grass Eragrostis plana (Medeiros et al., 2009) and other woody species (Guadagnin et al., 2009), constitute a threat to the integrity of ecosystems. Only $0.33 \%$ of the grasslands are currently protected by conservation areas in the state of Rio Grande do Sul (Overbeck et al., 2007). That is, most of the conservation of the areas still maintaining natural ecosystem characteristics and the high biodiversity of the grasslands is in the hands of private farmers that use traditional grazing management (Cordeiro and Hasenack, 2009).

\section{Original Soil Carbon Stocks}

Comprehensive studies on most biogeochemical cycles in the southern Brazilian grasslands are lacking. Some data on $\mathrm{C}$ stocks are available, mostly related to various grazing systems or agro-ecosystems established on grasslands. At the biome scale, other elements have been incompletely researched and datasets are at best patchy and inconsistent.

An estimate of original (potential) soil C stocks (0 to $30 \mathrm{~cm}$ depth) of the Pampa biome was derived from a statewide soil $\mathrm{C}$ stock inventory that included pedons sampled from the mid-1960s to the 1980s in Rio Grande do Sul (Tornquist et al., 2009a) (Figure 2). The original total soil $\mathrm{C}$ stock in the area comprising the Pampa biome was $1.0745,9 \mathrm{Tg}\left(\mathrm{Tg}=10^{12} \mathrm{~g}\right)$. The mean $\mathrm{C}$ density was $6.8 \mathrm{~kg} \mathrm{C} . \mathrm{m}^{-2}(0-30 \mathrm{~cm})$. Most soil C was stored in Neossolos, Argissolos, Planossolos and Latossolos (similar to Entisols, Inceptisols, Ultisols and Oxisols in Soil Taxonomy). The limited number of pedons available for some soil classes of this dataset somewhat compromised the accuracy of the estimates. Nevertheless, the database developed was essentially the most comprehensive available for the state of Rio Grande do Sul for soils in their original native condition. Refinements of these estimates of original C stocks would require new soil sampling in areas deemed to be representative of native vegetation before land cover was affected by human activities. Moreover, a contemporary $\mathrm{C}$ stock assessment derived from new sampling campaigns in cropped or other managed lands in the southern grasslands is urgently necessary for accurate representation of the current status of this biome in the national carbon inventories. 


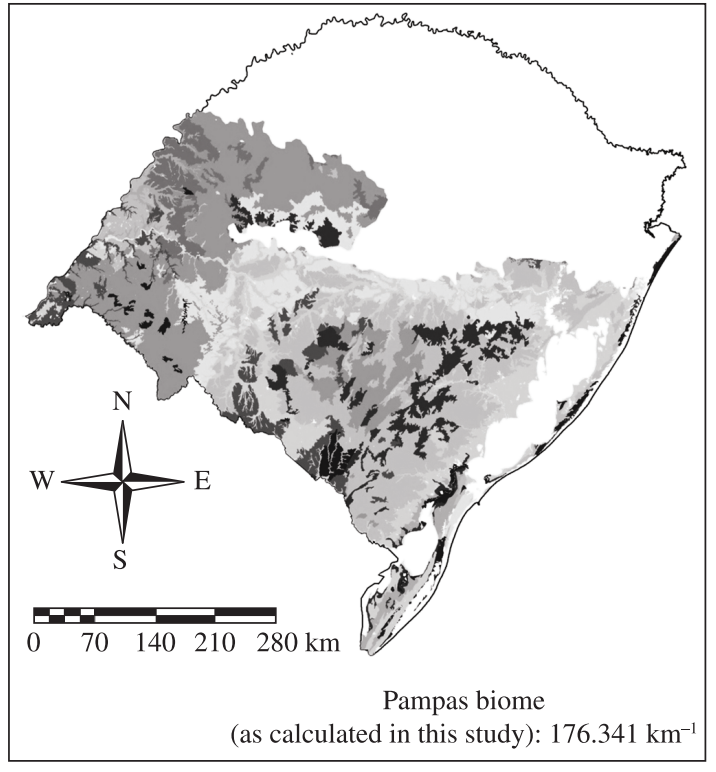

\begin{tabular}{|cc|}
\hline Soil C stocks $(0-30 \mathrm{~cm}) \mathrm{kg} \cdot \mathrm{m}^{-2}$ \\
$\square 0,000000$ & $\square 0,000001-3,802000$ \\
$\square 3,802001-4,318000$ & $\square 4,318001-5,095000$ \\
$\square 5,095001-5,347000$ & $\square 5,347001-6,488000$ \\
$\square 6,488001-7,717000$ & $\square 7,717001-9,307000$ \\
$\square 9,307001-16,245000$ & \\
\hline
\end{tabular}

Figure 2. Original soil organic carbon stocks in the grassland (Pampa) biome in southern Brazil. Sources: modified from RADAMBRASIL soil survey (1986) and UFRGS Soil Department soil profiles.

\section{Soil Carbon Dynamics Under Grassland Management}

Improvement in grazing management by adjusting stocking rates to the seasonal changes of biomass production has been shown to increase soil $\mathrm{C}$ in grasslands. A grazing experiment in Hulha Negra (Rio Grande do Sul) compared four grazing pressures $(4,8,12$ e $16 \% \mathrm{~kg}$ of dry matter of aboveground biomass available for kilogram of cattle live weight) for several years (Conceição et al., 2007). At the end of the experimental period a significant increase in soil $\mathrm{C}$ content under the lowest grazing pressure was observed. Soil C stocks $(0-40 \mathrm{~cm})$ varied from $103 \mathrm{Mg}$. $\mathrm{ha}^{-1}$ under high grazing pressure $(4 \%)$ to $140 \mathrm{Mg} \cdot \mathrm{ha}^{-1}$ under lower grazing pressures $(8,12$ and $16 \%)$, which presented similar $\mathrm{C}$ stocks.

The increased $\mathrm{C}$ storage found under better grazing management is attributed to the greater net primary production (NPP) of the pastures, which implies in larger aboveground and belowground $\mathrm{C}$ inputs to the soil. There are concerns regarding the amount of enteric methane emissions from domestic ruminants and their effect on the balance of greenhouse gases emissions in grassland ecosystems (Steinfeld et al., 2006). Data on enteric methane emissions in the southern Brazilian grassland ecosystems are needed in order to have reliable estimations of the balance of greenhouse gases emissions. Nevertheless, the increase in soil and biomass carbon produced by improved grazing management may offset ruminant methane emissions (Conant, 2010; Conant et al., 2001). Furthermore, it has been shown that grasslands likely act as large atmospheric CO2 sinks in Europe (Soussana et al., 2007) and in North America (Schuman et al., 2002).

\section{Carbon Dynamics after Grassland Conversion to Agriculture}

Agriculture development in the southern grasslands in the state of Rio Grande do Sul was based on conventional management practices that had a strong negative influence on soil C stocks. An early assessment of soil C stock changes in Southern Brazil verified that $50 \%$ of total soil C was lost in a short-time (10-15 years) under conventional tillage in Southern Brazil (Pottker, 1977). Soils usually function as a net source of GHG when native lands are converted to conventionally-managed crop fields (Robertson et al., 2000; Mosier et al., 2005). This behaviour is driven by the fast depletion of $\mathrm{C}$ stored in soil as organic matter $(\mathrm{SOM})$, as consequence of a negative balance between net $\mathrm{C}$ uptake by plants and $\mathrm{C}$ losses to atmospheric $\mathrm{CO}_{2}$ due to the microbial oxidation of soil organic matter (Amado et al., 2006; Bayer et al., 2006). The worst scenario is experienced when conventional tillage practices are associated with low biomass input crop systems or fallow periods, mainly under highly favourable temperature and soil moisture conditions to biological decomposition in humid tropical and subtropical climates (De Bona et al., 2008; Zanatta et al., 2007).

In contrast, soils under conservation management systems may act as a sink of $\mathrm{C}$ from atmosphere, but, in general, only a partial recovery of lost soil $\mathrm{C}$ from the native ecosystem should be expected. No-till is the most widespread conservation management technique, where an area of ca. 25 Mha is estimated in Brazil (Derpsch et al., 2010). Less oxidative environment in no-till soil results in carbon accumulation in comparison with conventional tillage techniques, and annual rates of $0.48 \mathrm{Mg} \mathrm{C} \mathrm{ha}^{-1}$ are estimated for subtropical soils from Southern Brazil (Bayer et al., 2006). These rates of $\mathrm{C}$ sequestration are similar or even higher than values verified in temperate soils, for example from United States, varying from 0.24 to $0.40 \mathrm{Mg} \cdot \mathrm{ha}^{-1} \cdot \mathrm{yr}^{-1}$ (mean of $0.3 \mathrm{Mg} \cdot \mathrm{ha}^{-1} \cdot \mathrm{yr}^{-1}$ ) (Lal et al., 1999; West and Marland, 2002).

Similar results were observed in a study by Tornquist et al. (2009b), where intensive field sampling, scenario development, and dynamic modeling were used to simulate changes in soil organic $\mathrm{C}$ on grasslands in the Ibirubá region (North-Central Rio Grande do Sul). The dominant soil order in the area is deep, very clayey Latosols. The simulations with the Century model (Metherel et al., 1993) showed a marked loss of soil $C$ when grasslands were converted to intensively-cultivated cropland, followed by a partial recovery of $\mathrm{C}$ stocks (C sequestration) when 
conservation management such as minimum tillage and no tillage were adopted (Figure 3).

\section{Greenhouse Gas Fluxes from Soil}

Conservation soil management systems have been promoted as a feasible alternative to mitigation of GHG emissions from agricultural soils (Mosier et al., 2006; Robertson et al., 2000; Six et al., 2004; Blanco-Canqui and Lal, 2008). No-tillage appears as the main practice in conservation agriculture and its favourable effect on soil $\mathrm{C}$ balance is very well documented (Amado et al., 2006; Bayer et al., 2006; Bono et al., 2008).

In a recent study, a balance of GHG emissions was performed in two long-term experiments at the UFRGS Agronomic Experimental Station near to Eldorado do Sul county. The effect of tillage (conventional and no-tillage) and crop rotations, involving grass and legume cover crops, on net global warming potential (GWP) in two long-term (18 and 20 years) experiments in a subtropical Paleudult in southern Brazil was evaluated. The main results are presented in Figure 4. Tillage systems and crop rotations had a significant effect on $\mathrm{CO}_{2}-\mathrm{C}$ retention rates and $\mathrm{N}_{2} \mathrm{O}$ fluxes, while typically low $\mathrm{CH}_{4}$ fluxes were observed among all soil management systems in this subtropical soil (Figure 4a,b,c). Similar results have been reported for temperate soils by Robertson et al. (2000) and Mosier et al. (2005, 2006) whose results demonstrated that the effect of soil management systems on $\mathrm{CO}_{2}$ and $\mathrm{N}_{2} \mathrm{O}$ fluxes may drive agricultural soils role as a net source or net sink for GWP.

Soil $\mathrm{N}_{2} \mathrm{O}$ emissions represented from 34 to $51 \%$ of total sources for GHG in no-tillage soil. The magnitude

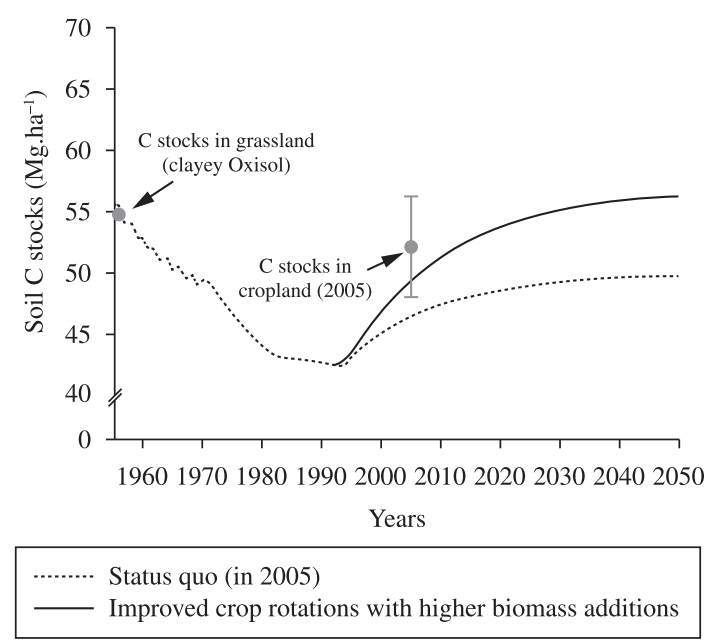

Figure 3. Century simulations of grassland conversion (in 1955) to two alternative agricultural scenarios in Latossolos (Oxisols) of Ibirubá, RS. "Status quo" represents actual agricultural practices as established in historical records and field surveys in 2005; "improved crop rotations" scenario depicts a cropping system with 30\% higher biomass production, such as corn and cover crops. Both scenarios assume adoption of no till soil management in 1992 (Tornquist et al. 2009b). of soil $\mathrm{N}_{2} \mathrm{O}$ emission rates in our study was similar to values reported for temperate soils in the literature. Long-term no-till system subjected to legume cover crops-based crop rotations resulted in higher soil $\mathrm{N}_{2} \mathrm{O}$ emissions than conventionally tilled soil and grass-based crop rotation (Figure 4b). Higher soil $\mathrm{N}_{2} \mathrm{O}$ emissions in legume cover crops-based crop rotation occur due to the increase in the net $\mathrm{N}$ mineralisation from narrow $\mathrm{C}: \mathrm{N}$ crop residues and from soil organic matter, supplying $\mathrm{NH}_{4}{ }^{+}$and $\mathrm{NO}_{3}{ }^{-}$to nitrification and denitrification processes in soil, respectively (Baggs et al., 2006). On the other hand, the no-tillage effect increasing $\mathrm{N}_{2} \mathrm{O}$ emission (Robertson et al., 2000) has been mainly related to a negative influence of soil compaction on $\mathrm{O}_{2}$ diffusion (Ball et al., 1999), but there are evidences in literature that higher $\mathrm{N}_{2} \mathrm{O}$ fluxes in no-tillage soil are related to anaerobic conditions created in patches of high microbial activity in the surface soil layer as a consequence of the high input of narrow $\mathrm{C}: \mathrm{N}$ biomass, such as legume crop residues, and soil organic matter (Baggs et al., 2006). This hypothesis is reinforced by the significant and direct relationship between $\mathrm{N}_{2} \mathrm{O}$ fluxes and dissolved organic $\mathrm{C}$ in soil in the period immediately following the crop residues management with glyphosate and knife-roller (Gomes et al., 2009). However, the notill system and legume cover crops-based crop rotations effects increasing $\mathrm{N}_{2} \mathrm{O}$ emission rates (59 to $168 \mathrm{~kg} \mathrm{CO}_{2}-\mathrm{C}$ equivalent $\mathrm{ha}^{-1} \cdot \mathrm{yr}^{-1}$ ) were fully compensated by the $\mathrm{CO}_{2}-\mathrm{C}$ retention rates in soils under these management systems ( -562 to $\left.-1047 \mathrm{~kg} \mathrm{CO}_{2}-\mathrm{C} \mathrm{ha}^{-1} \cdot \mathrm{yr}^{-1}\right)$. In contrast, soils under conventional tillage, independent of crop rotation, and no-tillage system under low biomass input grass-based crop rotation, had smaller $\mathrm{N}_{2} \mathrm{O}-\mathrm{N}$ emissions, but a dramatic decrease was observed in soil organic carbon (SOC) stock and, thus, the increased $\mathrm{CO}_{2}-\mathrm{C}$ flux in soil surpassed the lower $\mathrm{N}_{2} \mathrm{O}$ emission in these soil management systems (Figure 4a). These results show that no-tillage adoption contributes to decrease the agricultural soil contribution to GHG emissions to atmosphere, but efforts should be improved aiming to the adoption by farmers of high biomass crop rotations in order to get the regional agricultural soils more effective sinks of GHG.

The main GHG emissions $\left(\mathrm{CO}_{2}-\mathrm{C}, \mathrm{N}_{2} \mathrm{O}, \mathrm{CH}_{4}\right.$ and $\mathrm{C}$-cost) were totalised in a global warming potential (GWP) considering the different global warming potential of each gas in comparison to $\mathrm{CO} 2$ (25 for $\mathrm{CH}_{4}$ and 298 for $\mathrm{N}_{2} \mathrm{O}$ ) (Figure 6). The soil $\mathrm{CO}_{2}-\mathrm{C}$ retention rates primarily drove the management effect on net GWP (Figures 4a and 6). Thus, a net sink for GWP was verified in soil under no-tillage and legume cover crops-based crop rotations varying from -234 to $-768 \mathrm{~kg} \mathrm{CO}_{2}-\mathrm{C}$ equivalent $\mathrm{ha}^{-1} \cdot \mathrm{yr}^{-1}$. The crucial role of $\mathrm{CO}_{2}-\mathrm{C}$ retention resulting in a sink for GWP in no-till soil was also reported in other three studies performed in temperate regions of US (Robertson et al. 2000; Mosier et al. 2005; Mosier et al. 2006).

However, there is evidence that in the long run, soil $\mathrm{CO}_{2}-\mathrm{C}$ retention rates decrease in set aside soils (Robertson et al., 2000), and the same behaviour has been expected in no-till soils. In fact, this long-term ( $>30 \mathrm{yrs}$ ) 


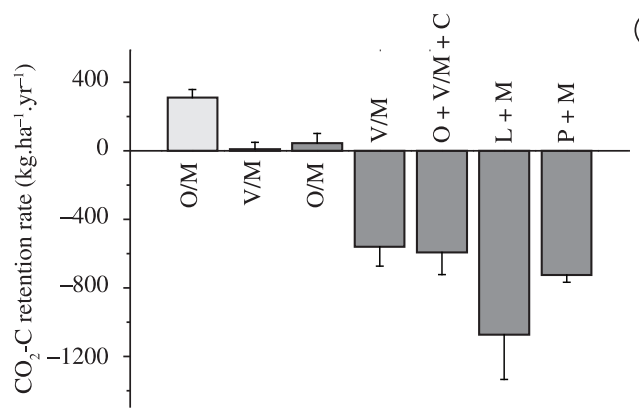

(a)
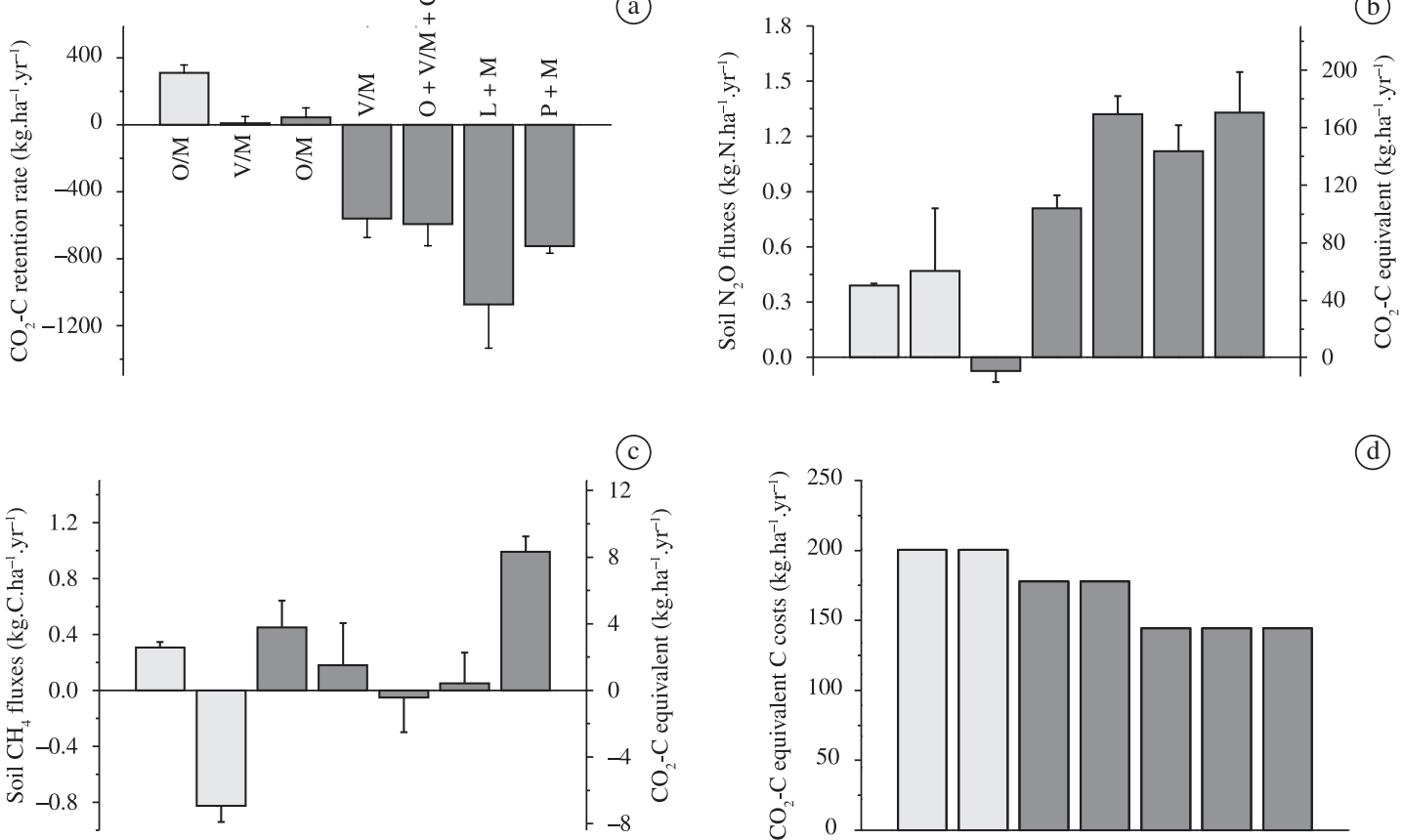

Tillage systems and crop rotations

Tillage systems and crop rotations

\section{$\square \mathrm{CT} \quad \square \mathrm{NT}$}

Figure 4. Soil carbon retention rates, nitrous oxide $\left(\mathrm{N}_{2} \mathrm{O}\right)$ fluxes, methane $\left(\mathrm{CH}_{4}\right)$ fluxes, and carbon cost of agricultural practices and agronomic inputs in a subtropical Paleudult subjected to tillage systems (conventional tillage-CT and no-tillageNT) and crop rotations (fallow/maize-F/M, oat/maize-O/M, vetch/ maize-V/M, oat + vetch/maize + cowpea-O + V/M + C, lablab + maize-L $+\mathrm{M}$, pigeon pea + maize-P $+\mathrm{M})$. Vertical lines are the mean standard error values $( \pm \mathrm{SE})$. Note that axes have different scales.

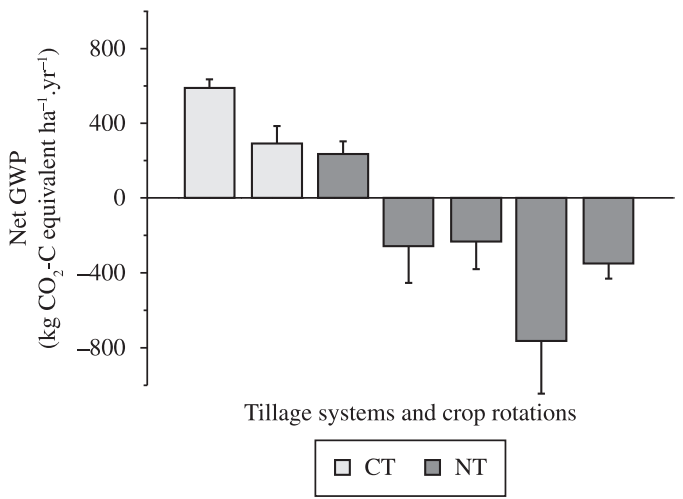

Figure 5. Net global warming potential (GWP) in a subtropical Paleudult subjected to tillage systems (conventional tillage-CT and no-tillage-NT) and crop rotations $(\mathrm{O} / \mathrm{M}, \mathrm{V} / \mathrm{M}, \mathrm{O}+\mathrm{V} / \mathrm{M}+\mathrm{C}, \mathrm{L}+\mathrm{M}, \mathrm{P}+\mathrm{M})$. Crop designation is presented in the footnote of the Table 1. Vertical lines represent the mean standard error values $( \pm \mathrm{SE})$.

trend of SOC contents stabilization has been reported in the literature (Del Grosso et al., 2002; Bayer et al., 2006; Zanatta et al., 2007) and, thus, a decrease of $\mathrm{CO}_{2}-\mathrm{C}$ retention rates in no-till soils should be expected in the long run.
However, one important gap of knowledge that remains regards how long $\mathrm{CO}_{2}-\mathrm{C}$ retention in no-till soils will be able to compensate the increased soil $\mathrm{N}_{2} \mathrm{O}-\mathrm{N}$ fluxes. Additionally, this timeframe is probably site-specific due to the effect of soil type and climate conditions on SOC dynamics.

\section{Final Remarks}

The research on carbon and greenhouse gases emissions in the southern Brazilian grassland biome is recent and the results are still fragmented. Nevertheless, the available data we reviewed allowed us to conclude that the southern Brazilian natural grassland ecosystems under adequate management contain important stocks of soil organic carbon in the soil, and therefore their conservation is relevant for the mitigation of climate change. Further, these ecosystems show a great and rapid loss of soil organic carbon when converted to crops based on conventional tillage practices. However, in the already converted areas there is potential to mitigate greenhouse gas emissions by using crop systems based on legume-based crop rotations combined with no soil tillage, and the effect is mainly related to the potential of these crop systems to accumulate organic carbon in the soil at rates that surpass the increased soil nitrous oxide emissions. Farm and research station data on emissions 
of greenhouse gases and soil $\mathrm{C}$ and $\mathrm{N}$ stocks should be modelled and integrated with geographic information systems into spatially explicit databases in order to allow regional and biome-scale inventories.

\section{References}

AMADO, TJC., BAYER, C., CONCEIÇÃO, PC., SPAGNOLLO, E., CAMPOS, BC. and VEIGA, M., 2006. Potential of carbon accumulation in no-till soils with intensive use and cover crops in Southern Brazil. Journal of Environmental Quality, vol. 35, p. 15991607. PMid:16825480. http://dx.doi.org/10.2134/jeq2005.0233

BAGGS, EM., CHEBII, J. and NDUFA, JK., 2006. A shortterm investigation of trace gas emissions following tillage and no-tillage of agroforestry residues in western Kenya. Soil and Tillage Research, vol. 90, p. 69-76. http://dx.doi.org/10.1016/j. still.2005.08.006

BALL, BC., SCOTT, A. and PARKER, JP., 1999. Field N2O, $\mathrm{CO} 2$ and $\mathrm{CH} 4$ fluxes in relation to tillage, compaction and soil quality in Scotland. Soil and Tillage Research, vol. 53, p. 29-39. http://dx.doi.org/10.1016/S0167-1987(99)00074-4

BAYER, C., MARTIN-NETO, L., MIELNICZUK, J., PAVINATO, A. and DIECKOW, J., 2006. Carbon sequestration in two Brazilian Cerrado soils under no-till. Soil and Tillage Research, vol. 86, p. 237-245. http://dx.doi.org/10.1016/j.still.2005.02.023

BEHLING, H., JESKE-PIERUSCHKA, V., SCHÜLER, L. and PILLAR, VD., 2009. Dinâmica dos campos no sul do Brasil durante o Quaternário Tardio. In PILLAR, VD., MÜLLER, SC., CASTILHOS, ZMS. and JACQUES, AVA. (Eds.). Campos Sulinos: Conservação e Uso Sustentável da Biodiversidade Brasília: Ministério do Meio Ambiente. p. 13-25.

BEHLING, H. and PILLAR, VD., 2007. Late Quaternary vegetation, biodiversity and fire dynamics on the southern Brazilian highland and their implication for conservation and management of modern Araucaria forest and grassland ecosystems. Philosophical Transactions Royal Society B, vol. 362, p. 243-251. PMid:17255033. PMCid:2311428. http://dx.doi.org/10.1098/ rstb.2006.1984

BEHLING, H., PILLAR, VD. and BAUERMANN, SG., 2005. Late Quaternary grassland (Campos), gallery forest, fire and climate dynamics, studied by pollen, charcoal and multivariate analysis of the São Francisco de Assis core in western Rio Grande do Sul (southern Brazil). Review of Palaeobotany and Palynology, vol. 133, p. 235-248. http://dx.doi.org/10.1016/j. revpalbo.2004.10.004

BENCKE, GA., 2009. Diversidade e conservação da fauna dos Campos do Sul do Brasil. In PILLAR, VD., MÜLLER, SC., CASTILHOS, ZMS. and JACQUES, AVA. (Eds.). Campos Sulinos: Conservação e Uso Sustentável da Biodiversidade Brasília: Ministério do Meio Ambiente. p. 101-121.

BLANCO-CANQUI, H. and LAL, R., 2008. No-tillage and soil-profile carbon sequestration: an on-farm assessement. Soil Science Society of America Journal, vol. 72, p. 693-701. http:// dx.doi.org/10.2136/sssaj2007.0233

BOLDRINI, II., 2009. A flora dos Campos do Rio Grande do Sul. In PILLAR, VD., MÜLLER, SC., CASTILHOS, ZMS. and JACQUES, AVA. (Eds.). Campos Sulinos: Conservação e Uso Sustentável da Biodiversidade Brasília: Ministério do Meio Ambiente. p. 63-77.
BONO, A., ALVAREZ, R., BUSCHIAZZO, DE. and CANTET, RJC., 2008. Tillage effects on soil carbon balance in a semiarid agroecosystem. Soil Science Society of America Journal, vol. 72, p. 1140-1149. http://dx.doi.org/10.2136/sssaj2007.0250

CONANT, RT., 2010. Challenges and opportunities for carbon sequestration in grassland systems: A technical report on grassland management and climate change mitigation. Roma: FAO. vol. 9.

CONANT, RT., PAUSTIAN, K. and ELLIOTT, ET., 2001. Grassland management and conversion into grassland: effects on soil carbon. Ecological Applications, vol. 11, p. 343-355. http:// dx.doi.org/10.1890/1051-0761(2001)011[0343:GMACIG]2.0.CO;2

CONCEIÇÃO, PC., BAYER, C., CASTILHOS, ZMS., MIELNICZUK, J. and GUTERRES, DB., 2007. Estoques de carbono orgânico num Chernossolo Argilúvico manejado sob diferentes ofertas de forragem no Bioma Pampa Sul-Riograndense. In Anais do 31nd Congresso Brasileiro de Ciência do Solo, 2007. Gramado, Rio Grande do Sul.

CORDEIRO, JLP. and HASENACK, H., 2009. Cobertura vegetal atual do Rio Grande do Sul. In PILLAR, VD., MÜLLER, SC., CASTILHOS, ZMS. and JACQUES, AVA. (Eds.). Campos Sulinos: Conservação e Uso Sustentável da Biodiversidade Brasília: Ministério do Meio Ambiente. p. 285-299.

DE BONA, FD., BAYER, C., DIECKOW, J. and BERGAMASCHI, H., 2008. Soil quality assessed by carbon management index in a subtropical Acrisol subjected to tillage systems and irrigation. Soil, Land Care \& Environmental Research, vol. 46, p. 469-475. http://dx.doi.org/10.1071/SR08018

DEL GROSSO, SJ., OJIMA, DS., PARTON, WJ. and MOSIER, AR., 2002. Simulated effects of tillage and timing of $\mathrm{N}$ fertilizer application on net greenhouse gas fluxes and $\mathrm{N}$ losses from agricultural soils in the Midwestern USA. In Proceedings of $3 r d$ Non-CO2 greenhouse gases Conference, 2002. Maastricht: Millpress. p. 23-29.

DERPSCH, R., FRIEDRICH, T., KASSAM, A. and LI, HW., 2010. Current status of adoption of no-till farming in the world and some of its main benefits. International Journal of Agricultural and Biological Engineering, vol. 3, p. 1-25.

DÜMIG, A., SCHAD, P., RUMPEL, C., DIGNAC, M-F. and KÖGEL-KNABNER, I., 2008. Araucaria forest expansion on grassland in the southern Brazilian highlands as revealed by $14 \mathrm{C}$ and $\delta 13 \mathrm{C}$ studies. Geoderma, vol. 145, p. 158-173.

GEAHL, AM., MELO, MS. and MORO, RS., 2010. Pitangui, rio de contrastes: seus lugares, seus peixes, sua gente. Ponta Grossa: Editora da UEPG.

GOMES, J., BAYER, C., DE SOUZA COSTA, F., DE CÁSSIA PICCOLO, M., ZANATTA, JA., VIEIRA, FCB. and SIX, J., 2009. Soil nitrous oxide emissions in long-term cover crops-based rotations under subtropical climate. Soil and Tillage Research, vol. 45, p. 36-44. http://dx.doi.org/10.1016/j.still.2009.10.001

GUADAGNIN, DL., ZALBA, SM., GÓRRIZ, BC., FONSECA, CR., NEBBIA, AJ., CUEVAS, YA., EMER, C., GERMAIN, P., WENDLAND, EMDR., PERELLO, LFC., BASTOS, MCS., SANHUEZA, CC., MASCIADRI-BÁLSAMO, S. and VILLALOBOS, AE., 2009. Árvores e arbustos exóticos invasores no Pampa: questões ecológicas, culturais e sócio-econômicas de um desafio crescente. In PILLAR, VD., MÜLLER, SC., CASTILHOS, ZMS. and JACQUES, AVA. (Eds.). Campos Sulinos: Conservação e Uso Sustentável da Biodiversidade Brasília: Ministério do Meio Ambiente. p. 300-316. 
Instituto Brasileiro de Geografia e Estatística - IBGE, 2004. Mapa da vegetação do Brasil e Mapa de biomas do Brasil. Brasília: IBGE.

KOZERA, C., KUNIYOSHI, IS., GALVÃO, F. and CURCIO , GR., 2009. Composição florística de uma formação pioneira com Influência fluvial em Balsa Nova, PR, Brasil. Floresta, vol. 39, p. 309-322.

LAL, R., FOLLET, RF., KIMBLE, J. and COLE, CV., 1999. Managing U.S. cropland to sequester carbon in soil. Journal of Soil and Water Conservation, vol. 54, p. 374-381.

MACFADDEN, BJ., 1997. Origin and evolution of the grazing guild in new world terrestrial mammals. Trends in Ecology \& Evolution, vol. 12, p. 182-187. http://dx.doi.org/10.1016/S01695347(97)01049-5

- , 2005. Diet and habitat of toxodont megaherbivores (Mammalia, Notoungulata) from the late Quaternary of South and Central America. Quaternary Research, vol. 64, p. 113-124. http://dx.doi. org/10.1016/j.yqres.2005.05.003

MEDEIROS, RBD., SAIBRO, JC. and FOCHT, T., 2009. Invasão de capim-annoni (Eragrostis plana Nees) no bioma Pampa do Rio Grande do Sul. In PILLAR, VD., MÜLLER, SC., CASTILHOS, ZMS. and JACQUES, AVA. (Eds.). Campos Sulinos: Conservação e Uso Sustentável da Biodiversidade Brasília: Ministério do Meio Ambiente. p. 317-330.

MELO, MS., 2009. Aqüífero Furnas: urgência na proteção de mananciais subterrâneos em Ponta Grossa, PR. In Anais do Seminário Internacional "Experiências de Agendas 21 - Desafios do Nosso Tempo", 2009. Curitiba.

METHEREL, AK., HARDING, LA., COLE, CV. and PARTON, WJ., 1993. Century soil organic matter model. Agroecosystem version 4. Fort Collins: Natural Resources Ecology Laboratory, Colorado State Universty. 133 p. Great Plains Research System Technical Report, no. 4.

MORRIS, MG., 2000. The efects of structure and its dynamics on the ecology and conservation of arthropods in British grasslands. Biological Conservation, vol. 95, p. 129-142. http://dx.doi. org/10.1016/S0006-3207(00)00028-8

MOSIER, AR., HALVORSON, AD., PETERSON, GA., ROBERTSON, GP. and SHERROD, L., 2005. Measurement of net global warming potential in three agroecosystems. Nutrient Cycling in Agroecosystems, vol. 72, p. 67-76.

MOSIER, AR., HALVORSON, AD., REULE, CA. and LIU, XJ., 2006. Net global warming potential and greenhouse gas intensity in irrigated cropping systems in Northeastern Colorado. Soil Science Society of America Journal, vol. 35, p. 1584-1598.

OVERBECK, GE., MÜLLER, SC., FIDELIS, A., PFADENHAUER, J., PILLAR, VD., BLANCO, CC., BOLDRINI, II., BOTH, R. and FORNECK, ED., 2007. Brazil's neglected biome: The South Brazilian Campos. Perspectives in Plant Ecology, Evolution and Systematics, vol. 9, p. 101-116. http://dx.doi.org/10.1016/j. ppees.2007.07.005

OVERBECK, GE., MÜLLER, SC., PILLAR, VD. and PFADENHAUER, J., 2005. Fine-scale post-fire dynamics in southern Brazilian subtropical grassland. Journal of Vegetation Science, vol. 16, p. 655-664. http://dx.doi.org/10.1111/j.1654-1103.2005. tb02408.x

PILLAR, VD., MÜLLER, SC., CASTILHOS, ZMS. and JACQUES, AVA., 2009. Campos Sulinos: Conservação e Uso Sustentável da Biodiversidade. Brasília: Ministério do Meio Ambiente.
PILLAR, VD. and VÉLEZ, E., 2010. Extinção dos Campos Sulinos em Unidades de Conservação: um fenômeno natural ou um problema ético? Natureza \& Conservação, vol. 8, no prelo.

PORTO, A., 1954. História das Missões Orientais do Uruguai. Porto Alegre: Livraria Selbach.

POTTKER, D., 1977. Efeitos do tipo de solo, tempo de cultivo e da calagem sobre a mineralização da matéria orgânica em solos do Rio Grande do Sul. Porto Alegre: Universidade Federal do Rio Grande do Sul. 85 p. Dissertaçã de Mestrado em Ciência do Solo.

REID, AM. and HOCHULI, DF., 2007. Grassland invertebrate assemblages in managed landscapes: Effect of host plant and microhabitat architecture. Austral Ecology, vol. 32, p. 708-718. http://dx.doi.org/10.1111/j.1442-9993.2007.01767.x

ROBERTSON, GP., PAUL, EA. and HARWOOD, RR., 2000. Greenhouse Gases in Intensive Agriculture: Contributions of Individual Gases to the Radiative Forcing of the Atmosphere. Science, vol. 289, p. 1922-1925. PMid:10988070. http://dx.doi. org/10.1126/science.289.5486.1922

ROCHA, CH., 1995. Ecologia da paisagem e manejo sustentável em bacias hidrográficas: estudos do Rio São Jorge nos Campos Gerais do Paraná. Curitiba: Escola de Agronomia, Universidade Federal do Paraná, 1995. 176 p. Dissertaçã de Mestrado em Agronomia.

SCHUMAN, GE., JANZEN, HH. and HERRICK, JE., 2002. Soil carbon dynamics and potential carbon sequestration by rangelands. Environmental Pollution, vol. 116, p. 391-396. http:// dx.doi.org/10.1016/S0269-7491(01)00215-9

SIX, J., OGLE, SM., BREIDT, FJ., CONANT, RT., MOSIER, AR. and PAUSTIAN, K., 2004. The potential to mitigate global warming with no-tillage management is only realized when practised in the long term. Global Change Biology, vol. 10, p. 155-160. http://dx.doi.org/10.1111/j.1529-8817.2003.00730.x

SOUSSANA, J-F., 2009. Os desafios da ciência das pastagens européias são relevantes para os Campos Sulinos? In PILLAR, VD., MÜLLER, SC., CASTILHOS, ZMS. and JACQUES, AVA. (Eds.). Campos Sulinos: Conservação e Uso Sustentável da Biodiversidade Brasília: Ministério do Meio Ambiente. p. 331-344.

SOUSSANA, JF., ALLARD, V., PILEGAARD, K., AMBUS, P., AMMAN, C., CAMPBELL, C., CESCHIA, E., CLIFTONBROWN, J., CZOBEL, S., DOMINGUES, R., FLECHARD, C., FUHRER, J., HENSEN, A., HORVATH, L., JONES, M., KASPER, G., MARTIN, C., NAGY, Z., NEFTEL, A., RASCHI, A., BARONTI, S., REES, RM., SKIBA, U., STEFANI, P., MANCA, G., SUTTON, M., TUBA, Z. and VALENTINI, R., 2007. Full accounting of the greenhouse gas $(\mathrm{CO} 2, \mathrm{~N} 2 \mathrm{O}, \mathrm{CH} 4)$ budget of nine European grassland sites. Agriculture, Ecosystems \& Environment, vol. 121, p. 121-134. http://dx.doi.org/10.1016/j. agee.2006.12.022

STEINFELD, H., GERBER, P., WADDENAAR, T., CASTEL, V., ROSALES, M. and HAAN, C., 2006. Livestock's long shadow: environmental issues and options. Rome: FAO.

TORNQUIST, CG., GIASSON, E., MIELNICZUK, J., CERRI, CEP. and BERNOUX, M., 2009a. Soil organic carbon stocks of Rio Grande do Sul, Brazil. Soil Science Society of America Journal, vol. 73, p. 975-982. http://dx.doi.org/10.2136/sssaj2008.0112

TORNQUIST, CG., MIELNICZUK, J. and CERRI, CEP., $2009 \mathrm{~b}$. Modeling soil organic carbon dynamics in Oxisols of Ibiruba (Brazil) with the Century Model. Soil and Tillage Research, vol. 105, p. 33-43. http://dx.doi.org/10.1016/j.still.2009.05.005 
WEST, TO. and MARLAND, GA., 2002. Synthesis of carbon sequestration, carbon emissions, and net carbon flux in agriculture: comparing tillage practices in the United States. Agriculture, Ecosystems \& Environment, vol. 91, p. 217-232. http://dx.doi. org/10.1016/S0167-8809(01)00233-X
ZANATTA, JA., BAYER, C., DIECKOW, J., VIEIRA, FCB. and MIELNICZUK, J., 2007. Soil organic carbon accumulation and carbon costs related to tillage, cropping systems and nitrogen fertilization in a subtropical Acrisol. Soil and Tillage Research, vol. 94, p. 510-519. http://dx.doi.org/10.1016/j.still.2006.10.003 